\title{
Microfinance services for smallholder farmers: an assessment from rice farmers' expectations in Central Benin
}

\author{
Smith A. R. Dossou* (D, Augustin K. N. Aoudji, Albertine M. Houessou and Rodrigue S. Kaki
}

\author{
* Correspondence: smithdossou@ \\ yahoo.fr \\ School of Economics, \\ Socio-Anthropology and \\ Communication for Rural \\ Development, Faculty of \\ Agricultural Sciences, University of \\ Abomey-Calavi, Benin, 03, BP 2819 \\ Cotonou, Bénin
}

\begin{abstract}
This study analyzed the adequacy between credit supply and the expectations of rice farmers in Central Benin to define policies for improved agricultural-oriented financial services. A survey was conducted in October 2016 among 120 rice farmers randomly selected from six rice-farming villages. Data collected through structured and semi-structured interviews included the financial services offered by Microfinance Institutions, socio-demographic characteristics of rice farmers, their expectations and perception. Multivariate analysis combining hierarchical ascending cluster analysis and principal component analysis (PCA) was used to define the distinct groups of rice farmers according to their credit expectations. The unmet expectations of rice farmers for a credit scheme that suits their needs were identified based on the gaps between their expectations and perception. There were three rice farmers' clusters with distinct characteristics based on their expectations. These farmers were not satisfied with all the attributes of the current credit scheme. Pending the effectiveness of the agricultural bank, the approaches such as the inventory credit system are useful in facilitating credit access to smallholder farmers. It is also essential to combine credit supply with financial education and technical support in a system such as contract farming.
\end{abstract}

Keywords: Credit access, Rice farming, Expectations, Perception, Benin

\section{Background}

In Sub-Saharan Africa, the agricultural sector plays a key role in tackling poverty and promoting food security (Sheahan and Barrett 2014; Affognon et al. 2015). In Benin, it contributes $23 \%$ on average to gross domestic product (PNUD 2015) and employs about $47 \%$ of the country's active population (INSAE 2016).

Supplying farmers with adequate inputs could foster agricultural development (Shah et al. 2008). Several studies have demonstrated that credits have a beneficial effect on farm productivity and on the cash-flows of farmers' households (Rajagopalan 2000; Arif 2001; Dawar 2003; ONU 2005). Financing constraints in the agricultural sector, therefore, limit the productive capacity of poor farmers (Shah et al. 2008). This impedes the

(c) The Author(s). 2020 Open Access This article is licensed under a Creative Commons Attribution 4.0 International License, which permits use, sharing, adaptation, distribution and reproduction in any medium or format, as long as you give appropriate credit to the original author(s) and the source, provide a link to the Creative Commons licence, and indicate if changes were made. The images or other third party material in this article are included in the article's Creative Commons licence, unless indicated otherwise in a credit line to the material. If material is not included in the article's Creative Commons licence and your intended use is not permitted by statutory regulation or exceeds the permitted use, you will need to obtain permission directly from the copyright holder. To view a copy of this licence, visit http://creativecommons.org/licenses/by/4.0/. 
modernization of agriculture by decreasing the use of technological innovations (Adégbola et al. 2009; Tarchiani et al. 2017).

In the context of increasing demand for agricultural financing in developing countries, including Benin, commercial banks show a limited interest in financing this sector (Kodjo et al. 2003). Microfinance has, therefore, become the main supplier of agricultural finance (Wampfler and Lapenu 2002; Morvant-Roux et al. 2010). However, most microfinance institutions only fund agricultural activities with lower risk, such as agricultural trade, or agri-food processing. As a result, microfinance is less able of meeting most farmers' financing needs (Moses and Zangue 2017). This supports the need to develop microfinance schemes tailored to the farmers' needs in order to effectively strengthen their investment capacity and optimal management decisions. Documenting the specific requirements of farmers could assist the government and other stakeholders in agricultural funding in developing adequate policies to satisfy these requirements.

This study seeks to analyze the adequacy between credit supply and the expectations of rice farmers in Central Benin, in order to identify policies for improved agriculturaloriented financial services. Indeed, rice has progressively become a fundamental food in both rural and urban areas of Benin and contributes to food security (Konnon et al. 2014). However, the domestic supply does not fulfill the growing demand. This increased demand is reflected in massive imports, accounting for more than $60 \%$ of total consumption in 2013 (FAO 2015). In order to guarantee food self-sufficiency for rice, with the prospect of serving sub-regional and regional markets, it is essential to set up financing schemes tailored to the requirements of rice farmers.

The present study was built on an integrated framework combining the characteristics of rice farmers and their farms, the financial services offered (Kumar et al. 2012), the categorization of rice farmers according to their expectations (Aoudji et al. 2014), and the expectancy disconfirmation paradigm (Oliver 1980; Taylor 1997). It was hypothesized that rice farmers are unsatisfied with the current credit supply. Although this study was conducted in Central Benin, its practical interest was to provide policymakers in Sub-Saharan Africa with useful information for identifying the attributes of adequate agricultural credit from the microfinance institutions.

This paper is organized as follows. In the next section, the research methodology is presented. "Results" appear in section 3, and the discussion of those results is done in the "Discussion" section. The main conclusions and related policy recommendations are summarized in the "Conclusion" section.

\section{Methods}

\section{Data collection}

A survey was conducted in October 2016 in the district of Glazoué, a major rice production area (Allagbe and Biaou 2013) located in Central Benin (Fig. 1). The survey was based on semi-structured and structured interviews. The semi-structured interviews were conducted among the heads of microfinance institutions established in the study area. The interview focused on the services offered in general, the lowest and the ceiling amounts, the interest rate, the required guarantee, the duration, and the repayment terms. The structured interviews were conducted among 120 rice farmers 


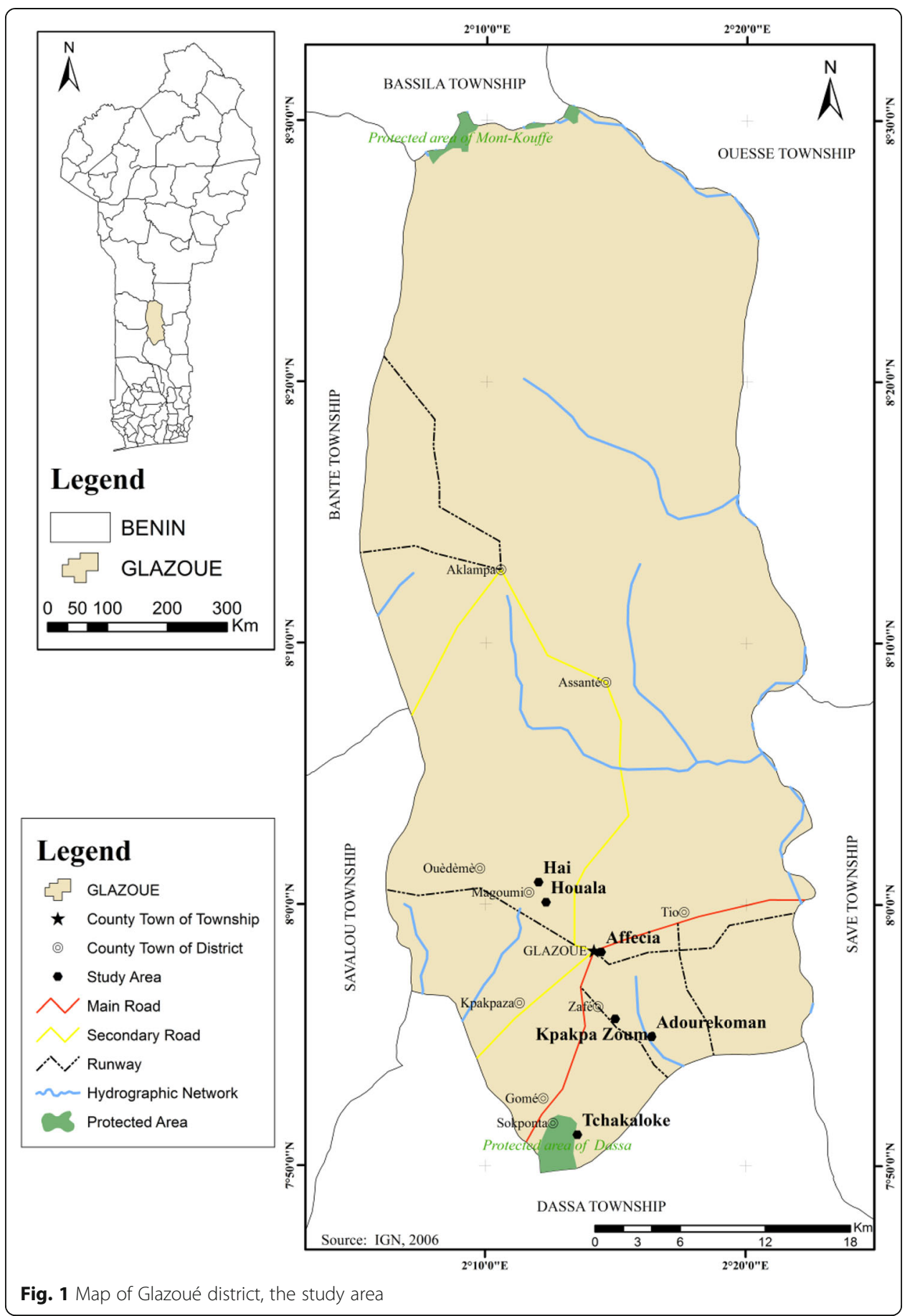

randomly selected in six villages. This sample was selected from 500 rice farmers identified in the district of Glazoué, which represents $24 \%$ of the total population. The questionnaire focused on rice farmers' socio-demographic characteristics, their expectations, and perception of the credit system.

A list of nine micro-credit attributes for agriculture was established for the assessment of expectations and perception of the credit scheme: affordable interest rate, flexibility of guarantee, geographical proximity of microfinance institutions, consideration 
of the farming calendar for the grace period, obtaining the amount requested, flexibility in the requirements of identity documents, credit granting to individuals, exemption from processing and other fees, timely processing of credit applications. These attributes were defined with rice farmers during an exploratory survey. Regarding the expectations, rice farmers were asked to value the importance of the attributes when applying for credit, by using a 7-point Likert scale, ranging from 1 (not at all important attribute) to 7 (very important attribute) (Kelley and Turley 2001; Ragaert et al. 2004). To assess rice farmers' perception of the credit scheme, the same attributes were used in the form of statements. Rice farmers were to tell their level of agreement on each attribute, by using a 7-point Likert scale ranging from 1 (strongly disagree) to 7 (strongly agree) (Bryhni et al. 2002).

\section{Data processing and analysis}

Data processing and statistical analysis included the characterization of the financial services, the identification of unsatisfied rice farmers' expectations for the credit scheme, and the categorization of rice farmers based on their expectations.

\section{Characterization of financial services}

The list of institutions offering financial services in the study region was established. The characterization of these institutions was done through a description of their services, the lowest and the ceiling amounts, the interest rate, the required guarantee, the duration, and the repayment terms.

\section{Identification of unsatisfied rice farmers' expectations for the credit scheme}

The average score of each attribute of expectations was calculated. An attribute is important to rice farmers when its average score equals at least 4 (the middle of the Likert scale used) (Kelley and Turley 2001). According to the expectancy disconfirmation framework (Oliver 1980; Taylor 1997), expectations of rice farmers are met for an attribute if the mean score of perception is consistently superior to that of expectations. This condition was checked for each important attribute previously identified by performing the Wilcoxon test.

\section{Categorization of rice farmers based on their expectations}

The rice farmer clusters were defined based on multivariate analyses. Hierarchical ascending cluster analysis was performed based on Ward's method, with the Euclidean distance as similarity index between the observations. The classificatory variables included the attributes of micro-credit for agriculture. Principal component analysis (PCA) was then performed to complement the hierarchical ascending cluster analysis (Glèlè-Kakaï and Kokodé 2004). The identified rice farmers' clusters were profiled based on the socio-demographic characteristics.

\section{Results}

\section{Socio-demographic characteristics of the sample}

The rice farmers surveyed were predominantly men, with about one-quarter of women in the sample (Table 1). Their age ranged between 25 and 75 years old. A quarter of 
Table 1 Socio-demographic characteristics of rice farmers

\begin{tabular}{|c|c|}
\hline Variable & Value \\
\hline \multicolumn{2}{|l|}{ Gender (\%) } \\
\hline Female & 29.2 \\
\hline Male & 70.8 \\
\hline \multicolumn{2}{|l|}{ Age (years) } \\
\hline Minimum & 25 \\
\hline First quartile & 34 \\
\hline Second quartile & 40 \\
\hline Third quartile & 47 \\
\hline Maximum & 75 \\
\hline \multicolumn{2}{|l|}{ Marital status (\%) } \\
\hline Married & 64.2 \\
\hline Single & 25.8 \\
\hline Divorced & 8.3 \\
\hline Widowed & 1.7 \\
\hline \multicolumn{2}{|l|}{ Education (\%) } \\
\hline None & 52.5 \\
\hline Primary level & 32.5 \\
\hline Secondary level & 14.2 \\
\hline University level & 0.8 \\
\hline \multicolumn{2}{|c|}{ Household size (number of individuals) } \\
\hline Minimum & 1 \\
\hline First quartile & 3 \\
\hline Second quartile & 5 \\
\hline Third quartile & 6 \\
\hline Maximum & 11 \\
\hline \multicolumn{2}{|c|}{ Surface area of rice producing (ha) } \\
\hline Minimum & 0.5 \\
\hline Mean & 1.49 \\
\hline Maximum & 5 \\
\hline Standard deviation & 0.97 \\
\hline \multicolumn{2}{|l|}{ Total farm size (ha) } \\
\hline Minimum & 1.5 \\
\hline Mean & 7.98 \\
\hline Maximum & 37 \\
\hline Standard deviation & 5.95 \\
\hline
\end{tabular}

them was under 34 years old, and half of them were over 47 years old (Table 1). About two-thirds of them were married. Singles represented one-quarter of the sample. The proportions of divorced and widowed were low, with a total of $10 \%$ (Table 1). More than half of the rice farmers surveyed did not attend school. About a third of them had primary school level; one-seventh had reached secondary school level and less than $1 \%$ had an advanced level (Table 1). Household size ranged between 1 and 11 people. Based on the quartiles, half of the households had 5 people, and one-quarter of them had more than 6 persons (Table 1). All of them were mainly engaged in agriculture. 
The acreage of rice lands varied between 0.5 and $5 \mathrm{ha}$, while the total farm size ranged between 1.5 and 37 ha among the farmers surveyed (Table 1).

\section{Characterization of financial services}

In the study region, the microfinance sector included two main categories of service providers: savings and credit institutions (five) and Non-Governmental Organizations with a micro-credit component (two). The functioning of four of the savings and credit institutions (80\%) depended mainly on the members' deposits. In addition to the members' deposits, traditional banks, government, and external aid funded only one institution. Through funding from external partners, the Non-Governmental Organizations provided credits to individuals.

Only the Non-Governmental Organizations (100\%) and two savings and credit institutions $(40 \%)$ offered their services to farmers in the form of short-term credits. The amounts of credit granted varied between XOF 10,000 (USD 17.24) and 5,000,000 (USD 8618.08), with a repayment term of 1 to 18 months. Concerning the rules for granting credit, nominal interest rates ranged between 1 and $2 \%$ per month, with a requirement including financial (15\% to $20 \%$ of prior savings) and material guarantees, as well as joint surety. The proportion of credits granted to agricultural activities in a year by these institutions varied on average between 5 and $20 \%$.

\section{Rice farmers' expectations on the credit scheme}

All nine attributes were important to rice farmers (Table 2). The comparison between perception and expectations scores showed that rice farmers were unsatisfied with all the attributes of the credit scheme (Table 2). Efforts are required to meet rice farmers' expectations in terms of agricultural financial services supply. The most important discrepancies between perception and expectations were recorded for the following attributes: timely processing of credit applications, geographic proximity of microfinance institution, and affordable interest rate. Particular attention must be paid to these attributes.

\section{Categorization of rice farmers based on their expectations}

Three rice farmers' clusters were identified based on their expectations (Fig. 2).

Table 2 Results of Wilcoxon test on the difference between the mean scores of perception and expectations

\begin{tabular}{lll}
\hline Attributes & Expectation & Perception \\
\hline Affordable interest rate & 6.74 & $3.75^{*}$ \\
Flexibility of guarantee & 6.34 & $3.39^{*}$ \\
Geographical proximity of microfinance institution & 6.58 & $3.31^{*}$ \\
Consideration of the farming calendar for the grace period & 6.48 & $3.85^{*}$ \\
Obtaining the amount requested & 6.38 & $3.92^{*}$ \\
Flexibility in the requirements of identity documents & 5.98 & $1.39^{*}$ \\
Credit granting to individuals & 6.29 & $3.84^{*}$ \\
Exemption from processing fees and other fees & 6.32 & $1.05^{*}$ \\
Timely processing of credit applications & 6.64 & $3.32^{*}$ \\
\hline
\end{tabular}

*Significant differences $(p<0.01)$. 


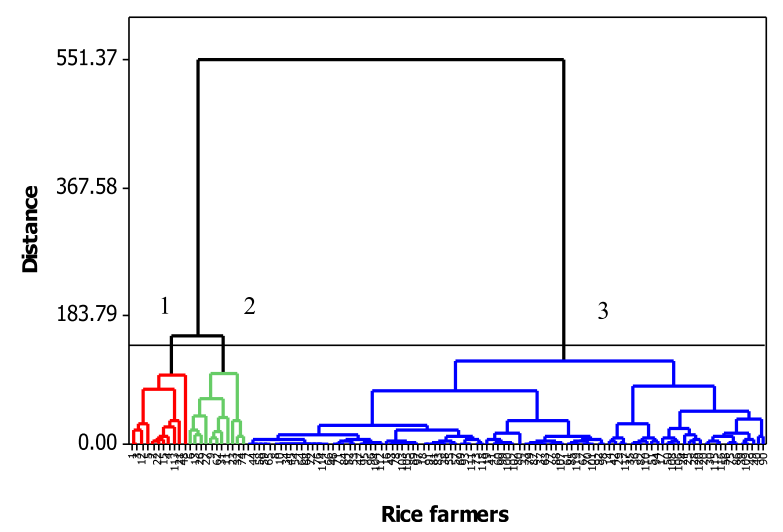

Fig. 2 Dendrogram showing the clusters identified from the hierarchical ascending classification. 1, 2, and 3 represent the numbering of the clusters

Those clusters were interpreted thanks to the principal components analysis (PCA). Based on the eigenvalues analysis of the correlation matrix (Table 3), the first three components could be used to interpret adequately the PCA results. Those components explained about $65 \%$ of the variability. The first principal component (PC1) explained most of the variation (39\%), the second principal component (PC2) explained 15\%, and the third (PC3) explained 11\%. The correlations between the principal components (PC) and the original variables (Table 4) showed that the PC1 was negatively correlated with consideration of the farming calendar for the grace period, obtaining the amount requested, exemption from processing and other fees, and timely processing of credit applications. The PC2 was negatively correlated with affordable interest rate and flexibility of guarantee. Concerning the $\mathrm{PC} 3$, it was negatively correlated with the geographical proximity of microfinance institution and positively correlated with flexibility in the requirements of identity documents and credit granting to individuals.

The factorial plans of the first three principal components (Figs. 3 and 4) are interpreted below, based on the correlations between principal components (PC) and original variables (Table 4$)$. Cluster 1 (9.16\% of the respondents) is composed of rice farmers who were looking for more affordable interest rates, flexibility in terms of guarantees, and proximity of microfinance institutions to their residential area. The second cluster ( $9.17 \%$ of respondents) is composed of rice farmers who were primarily looking for the proximity of microfinance institutions to their residential area. Finally, rice farmers in cluster 3 (81.67\% of respondents) valued the flexibility in the requirements of identity documents and the preference for individual credits (optional membership of a farmers organization). This cluster is also concerned with the following attributes: a grace period for the repayment suited to rice farming, obtaining the amount requested, no processing and other fees, and timely processing of credit applications.

The $\chi^{2}$ test showed significant differences in the frequency distribution between clusters for sex $\left(\chi^{2}=20.83, p=0.003\right)$, age $\left(\chi^{2}=56.26, p=0.042\right)$ and level of education $\left(\chi^{2}\right.$ $=27.24, p=0.024)$ (Table 5). The proportion of women in cluster 2 was comparable to the overall situation of the sample. This proportion was higher in cluster 1 and lower 
Table 3 Eigen analysis of the correlation matrix

\begin{tabular}{llllllllll}
\hline Parameters & PC1 & PC2 & PC3 & PC4 & PC5 & PC6 & PC7 & PC8 & PC9 \\
\hline Eigenvalue & 3.5220 & 1.3195 & 1.0001 & 0.9039 & 0.6456 & 0.5057 & 0.4473 & 0.3773 & 0.2785 \\
Proportion & 0.391 & 0.147 & 0.111 & 0.100 & 0.072 & 0.056 & 0.050 & 0.042 & 0.031 \\
Cumulative & 0.391 & 0.538 & 0.649 & 0.750 & 0.821 & 0.877 & 0.927 & 0.969 & 1.000 \\
\hline
\end{tabular}

PC Principal component

in cluster 3. Rice farmers under 30 years old were overwhelmingly represented in cluster 1, while rice farmers aged 31 to 45 predominated in clusters 2 and 3 (Table 5). Concerning the level of education, cluster 2 included nearly a quarter of rice farmers who had reached the university level, unlike clusters 1 and 3 (Table 5). Marital status did not vary across clusters. Rice farmers were married in the majority (Table 5). Regarding household size, no consistent differences were found across clusters (Table 5). As for the total acreage of land used by the rice farmers, clusters 1 and 3 were similar, with the majority of rice farmers using less than 5 ha of land. Among the majority of respondents and regardless of the cluster, rice cultivation occupied between 10 and $50 \%$ of the total acreage (Table 5).

\section{Discussion}

\section{Characterization of financial services}

The access of rice farmers to financial services in the study region was low. This reflects the general national trend. Only 5\% of farmers in Benin had access to formal credit (Allogni et al. 2010). In addition, the supply of financial services is mainly focused on short-term credit. Rice farmers are therefore unable to use this credit for their investments-a limitation for rice production development. This situation could stem from the fact that financing agricultural activities is generally costly, riskier, and less profitable for microfinance institutions (Chalmers 2005). Furthermore, most of these institutions depend on external funding, mainly from donors (Hunguana et al. 2012), limiting their capacity to finance farmers. Efforts are needed to ensure the effectiveness of financial service to farmers. The effective integration of an insurance component would improve the supply of financial services for agricultural activities, including rice production. Previous studies suggested that an insurance component should be incorporated into the schemes for commercial agricultural credit to increase the credit flow

Table 4 Correlation between principal components $(\mathrm{PC})$ and original variables

\begin{tabular}{llll}
\hline Variables & PC1 & PC2 & PC3 \\
\hline Affordable interest rate & -0.170 & -0.643 & -0.285 \\
Flexibility of guarantee & -0.270 & -0.602 & -0.131 \\
Geographical proximity of microfinance institution & -0.272 & 0.178 & -0.537 \\
Consideration of the farming calendar for the grace period & -0.372 & 0.307 & -0181 \\
Obtaining the amount requested & -0.396 & 0.093 & -0.302 \\
Flexibility in the requirements of identity documents & -0.376 & -0.130 & 0.423 \\
Credit granting to individuals & -0.338 & 0.050 & 0.460 \\
Exemption from processing fees and other fees & -0.378 & 0.023 & 0.314 \\
Timely processing of credit applications & -0.362 & 0.263 & -0.016 \\
\hline
\end{tabular}




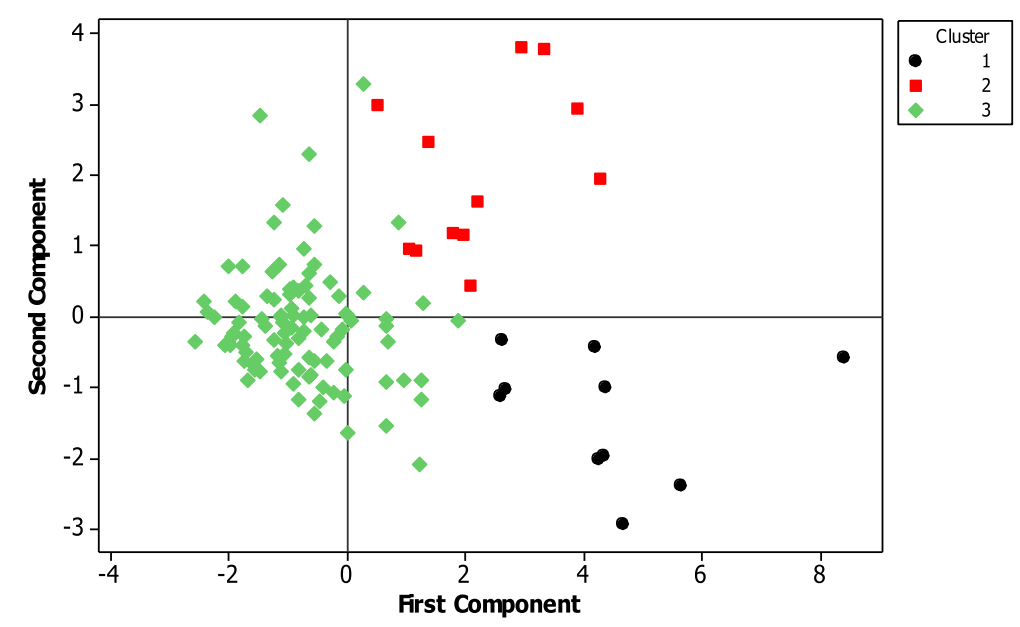

Fig. 3 Score plot for principal components 1 and 2 from PCA. Clusters from the hierarchical ascending classification are shown in black (cluster 1), red (cluster 2), and green (cluster 3 )

to the agricultural sector (Collier and Skees 2012; Polycarp and Odufote 2012; Collier et al. 2013). Many agricultural risks, including those relating to weather and markets, will be addressed by the insurance. Incorporating insurance has also the advantages of simplifying administrative arrangements for the financial service providers, reducing their lending risks. However, it could present some drawbacks for farmers who have other less costly ways of managing their risks. In this case, the insurance will simply increase the credit cost without adding proportionate benefits, making the credit less attractive.

Moreover, the government of the Republic of Benin is already committed to the establishment of an agricultural bank capable of meeting farmers' needs. However, it is important to innovate in credit supply and include a technical and management support (financial education) package to reduce the failure risks.

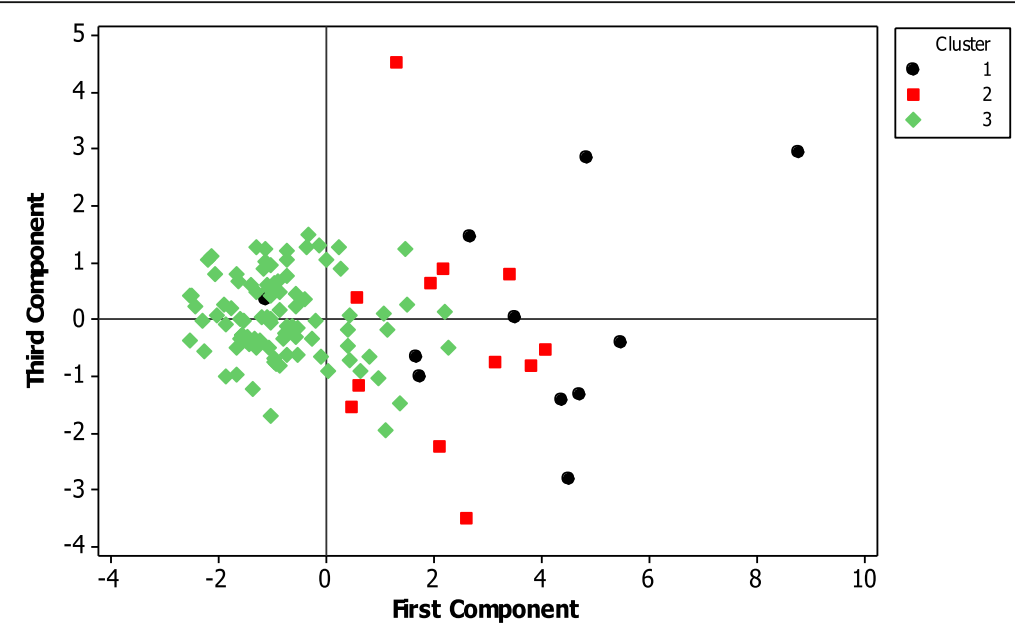

Fig. 4 Score plot for principal components 1 and 3 from PCA. Clusters from the hierarchical ascending classification are shown in black (cluster 1), red (cluster 2), and green (cluster 3) 
Table 5 Socio-demographic characteristics of rice farmers across the clusters

\begin{tabular}{|c|c|c|c|}
\hline \multirow{2}{*}{$\begin{array}{l}\text { Socio-demographic } \\
\text { characteristics }\end{array}$} & \multicolumn{3}{|l|}{ Clusters } \\
\hline & Cluster 1 & Cluster 2 & Cluster 3 \\
\hline \multicolumn{4}{|l|}{ Gender (\%) ** } \\
\hline Male & 56 & 74.8 & 83.33 \\
\hline Female & 44 & 25.2 & 16.66 \\
\hline \multicolumn{4}{|l|}{ Age (\%)* } \\
\hline$\leq 30$ & 40 & 11.11 & 10.93 \\
\hline $31-45$ & 36 & 55.55 & 57.81 \\
\hline$\geq 46$ & 24 & 33.34 & 31.26 \\
\hline \multicolumn{4}{|l|}{ Education (\%)* } \\
\hline None & 39.5 & 38.88 & 57.81 \\
\hline Primary level & 31.33 & 5.55 & 34.37 \\
\hline Secondary level & 23.5 & 33.33 & 7.81 \\
\hline University level & 5.67 & 22.22 & 0 \\
\hline \multicolumn{4}{|l|}{ Marital status (\%) } \\
\hline Married & 70 & 75 & 62.24 \\
\hline Single & 30 & 16.66 & 26.53 \\
\hline Divorced & 0 & 8.33 & 9.18 \\
\hline Widowed & 0 & 0 & 2.04 \\
\hline \multicolumn{4}{|l|}{ Household size (\%) } \\
\hline$\leq 2$ & 30 & 8.33 & 23.46 \\
\hline $3-5$ & 30 & 25 & 43.87 \\
\hline$\geq 6$ & 40 & 66.66 & 28.66 \\
\hline \multicolumn{4}{|l|}{ Farm size $(\%)^{*}$} \\
\hline$\leq 5$ ha & 43.5 & 27.77 & 40.63 \\
\hline 5-10 ha & 40 & 55.55 & 34.37 \\
\hline$>10$ ha & 16.5 & 16.66 & 24.99 \\
\hline \multicolumn{4}{|c|}{ Share of the acreage of rice land in the farm size (\%) } \\
\hline$\leq 10 \%$ & 8.33 & 8.33 & 14.46 \\
\hline $10-50 \%$ & 75 & 82 & 80.72 \\
\hline$\geq 51 \%$ & 17 & 9.77 & 4.82 \\
\hline
\end{tabular}

*Variable showing a significant difference in the frequency distribution between clusters $(p<0.05)$

**Variable showing a significant difference in the frequency distribution between clusters $(p<0.01)$

\section{Satisfaction of rice farmers' expectations towards credit supply}

As hypothesized, the rice farmers were unsatisfied with all attributes expected from the credit scheme. The dissatisfaction of rice farmers with the attribute "affordable interest rate" is not surprising. Previous studies pointed out the high-interest rate charged by microfinance institutions in rural and urban areas (ADB 2016; Hong and Hanson 2016). Furthermore, the interest rates charged by the microfinance institutions are high compared with market lending rates (between 9 and $15 \%$ per year) ${ }^{1}$. This stems from the fact that it is essentially the interest on the credits granted that allows the microfinance institutions to cover the various costs incurred (Kariuki and Ngahu 2016),

$\overline{{ }^{1} \text { http://www.izf.net/ancien/entreprise/num-4611 }}$ 
including borrowing from traditional banks. The reduction of costs incurred could be a solution to affordable interest rates. The future agricultural bank of Benin could make financial resources available to microfinance institutions on better terms. This would have cost implications but also a potentially high return on investment (improvement of productivity and income of farmers). The exemption from processing fees and other fees is related to the credit cost.

With regard to the attribute "flexibility of guarantee", apart from the joint surety for farmers organizations, the terms of the microfinance institutions were relatively restrictive. These findings are consistent with those of Razakaharivelo (2013), which revealed that more than a quarter of the women beneficiaries were not satisfied with the guarantees requested by the microfinance institutions in Madagascar. Despite the necessity for the microfinance institutions to keep rigorous about the issue of guarantee, they could consider other types of guarantees, such as the inventory credit system. Regarding the attribute "flexibility in the requirements of identity documents", the government should continue the ongoing efforts to provide each citizen with civil status documents. In the meantime, microfinance institutions may use witnesses who have valid civil status documents.

Regarding the issue of proximity, so far, most farmers are forced to travel long distances before accessing a microfinance institution, leading to extra expenses. The proximity of financial services is a key element for improved access to agricultural finance (Dhakal 2013). This proximity should improve with the increase of the solvent demand that would lead microfinance institutions to bring their agencies closer to optimize their activities. The introduction of credit reference bureaus is therefore an important policy issue for improved access to agricultural finance.

Rice producing and marketing activities last approximately 6 to 8 months, while credit repayment follows a monthly basis after a grace period of 1 to 3 months for the majority of microfinance institutions. These conditions do not allow rice farmers to harvest and market their products before starting repayment. Flexible repayment schemes adjusted to the financial flows of agricultural activities could make lending programs more accessible to farmers (Christen and Pearce 2005; Koumassa 2007). This includes the implementation of a monitoring mechanism and the education to finance management allowing the efficient use of credit. In this light, contract farming could be explored (Prowse 2012).

Although the credits are not supposed to cover all the financing needs of rice farmers, the amounts received are low to meet the annual rice production financing needs. Indeed, the average amount of credit granted to rice farmers surveyed by the microfinance institutions was XOF 232,633 (USD 400.97) per hectare; while the total cost for rice production per hectare in the study area was XOF 381,664 (USD 657.84) (Yabi 2013). This weakness in the volume of credits stems from the risk minimization strategies and the unavailability of the resources at the microfinance institutions (Kodjo et al. 2003; Niyongabo 2008; Sossou 2015). Generally, the undersupply of credit is due to information problems (adverse selection and moral hazard) leading to equilibrium credit rationing as discussed in the model of Stiglitz and Weiss (1981). Credit rationing is a frequent practice in financial markets. The future agricultural bank, as indicated above, could play a key role in the refinancing of microfinance institutions to improve farmers' financing mechanisms. 
The rice farmers mentioned their preference for individual credits. According to their perception, credits obtained through a farmers' organization are often used in the social sphere because of their non-discrete nature. To reduce the risks associated with the low repayment rate, microfinance institutions usually give credit either to solidarity groups of farmers who cannot provide material guarantees or individually to farmers with a little more collateral. Several studies demonstrated the benefits of joint surety for micro-credit beneficiaries and for microfinance institutions (Paxton 1996; Honlonkou 2002; Mauk 2013; Noglo and Androuais 2013). Rice farmers should be made aware of the performance of the Solidarity Credit Group.

Rice farmers' dissatisfaction about the attribute "timely processing of credit applications" stems from the long procedure in microfinance institutions, linked to the complexity of the compilation of the dossier (Pasha and Negese 2014). According to the rice farmers, a delay in the release of the credits affects the farming calendar, with many consequences: drop in yield, change in the destination of credit, and difficulties in the repayment of the credit. It could be useful in this context to sensitize farmers to request credit far in advance. Assistance in preparing the application could be also helpful.

\section{Categorization of rice farmers based on their expectations}

Three clusters of rice farmers were identified based on their expectations of a credit scheme suited to their activities. These clusters presented a variety of sociodemographic characteristics. Cluster 1 was composed of rice farmers who were relatively younger compared with the other clusters (2 and 3). They had a higher level of education compared with cluster 3 . These young rice farmers (cluster 1) had less financial and material resources to meet the requirements of microfinance institutions in terms of guarantees. This explains their desire for a more affordable interest rate, flexible modalities of guarantee, and proximity of microfinance institutions, unlike rice farmers in cluster 3 . This could also explain the concentration of women in this cluster. Rice farmers in cluster 2 had a high level of education compared with the other groups. This category of farmers (cluster 2) was more interested in the physical accessibility of the credit supply. The effect of borrower-lender distance results in a physical cost that farmers, in our case, need to bear to contract with microfinance institutions (Pedrosa and Do 2011). There is the direct transaction cost-transportation cost to obtain financial services from microfinance institutions-that farmers support. This is a barrier to accessing credit in rural areas.

Women were poorly represented in clusters 2 and 3 . This low proportion of women could stem from the difficulties related to rice farming and the limited access of these stakeholders to certain inputs, namely land. In Africa including Benin, women have limited access to land and other productive resources (World Bank 2011; Thiessen 2016). In the study area, women were more involved in growing legumes (soybeans and groundnuts) and especially in post-harvest activities (processing, marketing).

In general, the major lowlands development programs are not financed by the rice farmers themselves but are carried out under various programs and projects. However, improved rice farmers' access to adequate credit could allow them-in all those clusters-to grow more rice acreage, in order to increase their productivity, as well as their 
household cash-flow (Sulemana and Dinye 2016; Lawanson 2016). Conversely, households may demand credit, while their current income is high due to the expectations of future income, which will guarantee their repayment (Chen and Chiivakul 2008).

\section{Conclusion}

The present study analyzed the adequacy between credit supply and the expectations of rice farmers in Glazoué (Central Benin). Savings and short-term credits were the financial services offered by the microfinance institutions located in the study region. The average amount of credit obtained by the farmers surveyed was XOF 232,633 (USD 400.97) per hectare and the maximum duration for the repayment was 18 months. The monthly interest rates ranged from 1 to $2 \%$, with a guarantee required.

Based on their expectations for agricultural credit, rice farmers were divided into three clusters. The socio-demographic characteristics of the clusters were different. On the whole, rice farmers were not satisfied with the current credit supply. This result reflects the inadequacy between the current supply of microfinance institutions and the needs of rice farmers. Various alternatives have been discussed to develop a microcredit service that is more adapted to the needs and expectations of farmers without compromising the viability of microfinance institutions. The forthcoming creation of an agricultural bank in Benin could contribute to lift restrictions on access to finance, by building on microfinance institutions that are already trying to support farmers. Among other things, the provision of financial resources-at affordable conditions-to microfinance institutions will allow them to consider reducing interest rates. To reduce the risk of credit defaults, credit supply needs to be innovative by including a package of technical support and management (financial education). All this could be done through a contract farming system. In addition, the promotion of other types of accessible guarantees such as the inventory credit system would improve access to finance for rice farmers. There is a need to sensitize rice farmers on the benefits of Solidarity Credit Groups, and the submission of credit applications far in advance of the agricultural calendar, to anticipate the time required for the dossiers processing. Finally, the government must continue its ongoing efforts to provide each citizen with civil status documents as a cross-cutting measure.

Abbreviations

PCA: Principal component analysis; PC: Principal component

\section{Acknowledgements}

Not applicable for that section.

\section{Authors' contributions}

SARD designed the methodology of the study and performed the data analysis and interpretation. AKNA organized the data collection, institutional support, and provided useful policy insights to the research. AMH carried out the introduction and conclusion sections. RSK developed the questionnaire and carried out the data collection. All authors participated in the writing and revision of the manuscript. All authors read and approved the final manuscript.

Authors' information

Not applicable for that section.

Funding

Not applicable for that section.

Availability of data and materials

The datasets used and/or analyzed during the current study are available from the corresponding author on reasonable request. 


\section{Competing interests}

The authors declare that they have no competing interests.

Received: 29 December 2018 Accepted: 6 August 2020

Published online: 13 August 2020

\section{References}

ADB (2016) Impact of restrictions on interest rates in microfinance. In: Sustainable development working paper series no 45. Mandaluyong City, Philippines. https://www.adb.org/sites/default/files/publication/200141/sdwp-045.pdf. Accessed 20 Jan 2018

Adégbola PY, Adékambi SA, Tidjani Serpos AA (2009) Microfinance et production agricoles: cas de l'anacarde au Bénin. INRAB, Bénin https://images.agri-profocus.nl/upload/post/RapportFinancementanacarde_20091417443630.pdf. Accessed 11 Apr 2017

Affognon H, Mutungi C, Sanginga P, Borgemeister C (2015) Unpacking postharvest losses in sub-Saharan Africa: a metaanalysis. World Development 66:49-68

Allagbe MC, Biaou G (2013) Déterminants de l'adoption des variétés améliorées de riz NERICA dans les communes de DassaZoumé et de Glazoué au Bénin. Bulletin de la Recherche Agronomique du Bénin (BRAB) 74:48-59

Allogni WN, Coulibaly ON, Hell K, Mensah GA (2010) Liens entre la contamination des produits maïsicoles à l'aflatoxine et la pauvreté au Bénin. https://www.researchgate.net/profile/Guy_Mensah/publication/261700113_Liens_entre_la_ contamination_des_produits_maisicoles_a_l'aflatoxine_et_la_pauvrete/links/556b9df608aeccd7773a1c56.pdf. Accessed 04 Jun 2019

Aoudji AKN, Adégbidi A, Ganglo JC, Lebailly P (2014) Teak, Tectona grandis L.f., planting in smallholders' farming system in southern Benin. Bois et forêts des tropiques 319(1):7-17

Arif R (2001) Effect of micro-credit disbursed by ADBP on agricultural production in District Attock. M.Sc (Hons) Thesis, IDS, NWFP Agric. Univ, Peshawar, Pakistan

Bryhni EA, Byrne DV, Rodbotten C, Claudi-Magnussen C, Agerhem H, Johanson M, Lea P, Martens M (2002) Consumer perception of pork in Denmark, Norway and Sweden. Food Quality and Preference 13:257-266

Chalmers G (2005) A Fresh Look at Rural and Agricultural Finance. In: RAFI Note \#1, An AMAP/BASIS Publication, USAID's Rural and Agricultural Finance Initiative, Chemonics, ACDINOCA, Ohio State University and DAI

Chen KC, Chiivakul M (2008) What drives household borrowing and credit constraints? Evidence from Bosnia and Herzegovina. IMF Working Papers 08(202):1-31

Christen RP, Pearce D (2005) Managing risks and designing products for agricultural microfinance: Features of an emerging model. CGAP Occasional Paper, No. 11, Washington http://www.cgap.org/sites/default/files/researches/documents/CGAPOccasional-Paper-Managing-Risks-and-Designing-Products-for-Agricultural-Microfinance-Features-of-an-Emerging-ModelApr-2005.pdf. Accessed 04 Apr 2017

Collier B, Skees J (2012) Increasing the resilience of financial intermediaries through portfolio-level insurance against natural disasters. Natural Hazards 64:55-72

Collier BL, Miranda MJ, Skees JR (2013) Natural disasters and credit supply shocks in developing and emerging economies. Doctoral dissertation, University of Kentucky, Lexington, USA. https://pdfs.semanticscholar.org/a49e/26d8dc5f0f1 c531 c8325fb33c2c17014dbd8.pdf. Accessed 15 Dec 2017

Dawar SK (2003) A study of agricultural credit programme of ZTBL for small farmers of district Bannu. M.Sc (Hons) Thesis IDS, NWFP Agric. Univ. Peshawar

Dhakal NH (2013) Agricultural finance: credit unions focusing on the socio-economic empowerment of farmers. In: A paper prepared for presentation in Asian Credit Union Open Forum 2013. Kathmandu, Nepal

FAO (2015) Faostat. http://www.fao.org/faostat/fr/\#country/53. Accessed 25 Jun 2017

Glèlè-Kakaï R, Kokodé GG (2004) Techniques statistiques univariées et multivariées : applications sur ordinateur. In: Note technique de biométrie. INRAB, Cotonou, Bénin, pp 5-60

Hong D, Hanson S (2016) Scaling up agricultural credit in Africa: frontier issues brief submitted to the Brookings Institution's Ending Rural Hunger project. http://www.endingruralhunger.org/. Accessed 20 May 2017

Honlonkou AN (2002) Evaluation de la performance de remboursement dans les institutions de microfinance au Bénin Mondes en développement 3(119):73-77

Hunguana H, Ribeiro P, Mata T, Dlamini M, Mahlati V, Fitzpatrick K (2012) Status of agricultural and rural finance in Mozambique. In: FinMark Trust. http://finmark.org.za.dedi517.jnb2.host-h.net/wp-content/uploads/2016/01/Rep_ statusofAgRuFin_MOZ1.pdf. Accessed 29 Apr 2017

INSAE (2016) Principaux Indicateurs RGPH 2013 - Benin. http://benin.opendataforafrica.org/ohikebf/principaux-indicateursrgph-2013-benin?region=1000000-benin\&indicateur=1001030-population-active-de-15-64-ans. Accessed 24 Apr 2018

Kariuki MW, Ngahu S (2016) Effect of interest rates on loan performance of microfinance institutions in Naivasha Sub-County, Kenya. Int J Econ Commerce Manag 4(4):549-566

Kelley SW, Turley LW (2001) Consumer perception of service quality attributes at sporting events. J Business Res 54:161-166

Kodjo MKZ, Abiassi EH, Allagbe MC (2003) Le financement de l'agriculture béninoise dans un contexte de libéralisation: contribution de la microfinance. In: Cahier de Recherche ELIFID, Bénin

Konnon DD, Sotondji SC, Adidehou YA (2014) Rapport de l'étude de l'état des lieux de la filière riz au Bénin. http://www. inter-reseaux.org/IMG/pdf/Rapport_Final_Etat_des_Lieu_Riz_1_.pdf. Accessed 05 Sep 2017

Koumassa L (2007) La microfinance dans l'adoption de nouveaux paquets technologiques de production de riz dans le département des Collines au Bénin. Thesis of "Ingenieur Agronome", Faculty of Agronomic Sciences, University of Abomey-Calavi, Benin

Kumar B, Banga G, Jindal A (2012) Perception and attitude of farmers and agri firms towards commodity finance. NMIMS Management Review 22:89-111

Lawanson OI (2016) Alleviating poverty through microfinance: Nigeria's experience. Asian J Econ Modelling 4(3):153-161

Mauk P (2013) Modélisation Mathématique du Micro-crédit. Doctoral dissertation, University of Nice Sophia Antipolis 
Morvant-Roux S, Guérin I, Roesch M, Servet J-M (2010) Politiques d'inclusion financière, microfinance et financement de l'agriculture. Les cas de l'Inde et du Mexique. Mondes en développement 3(151):9-24

Moses AO, Zangue NJ (2017) Financial performances of microfinance institutions in cameroon: Case of CamCCUL Ltd. Int J Econ Finance 9(4):207-224

Niyongabo E (2008) Défis du financement agricole et rural, rôle pour la microfinance et implications pour les politiques publiques en Afrique Sub-Saharienne: Pistes de recherche basées sur le cas du Burundi. Working papers CEB, 8. http:// dipot.ulb.ac.be/dspace/bitstream/2013/54305/1/RePEc_sol_wpaper_08-024.pdf. Accessed 05 Jan 2018

Noglo YA, Androuais A (2013) Microfinance et performance de remboursement des groupes de crédits au Togo : une enquête de terrain auprès de deux institutions de microfinance (FUCEC et WAGES). http://www.erudite.univ-paris-est.fr/ evenements/colloques-et-conferences/atm-2013-communications-full-papers/?elD=dam_frontend_push\&docID=25269. Accessed 05 Sep 2017

Oliver RL (1980) A cognitive model of the antecedents and consequences of satisfaction decisions. J Marketing Res 17:460469

ONU (2005) Construire des secteurs financiers intégrants pour atteindre les objectifs de développement du millénaire. Extracts from the project document of the international year of micro-credit 2005

Pasha SAM, Negese T (2014) Performance of loan repayment determinants in Ethiopian microfinance-an analysis. Eurasian J Business Econ 7(13):29-49

Paxton JA (1996) Determinants of successful group loan repayment: an application to Burkina Faso. Doctoral dissertation, Ohio State University. https://etd.ohiolink.edu/!etd.send_file?accession=osu1487942476405252\&disposition=inline. Accessed 10 Dec 2018

Pedrosa J, Do QT (2011) Geographic distance and credit market access in Niger. African Development Review 23(3):289-299

PNUD (2015) Rapport national sur le développement humain 2015 : Agriculture, sécurité alimentaire et développement humain au Bénin. http://hdr.undp.org/sites/default/files/rndh_2015_benin.pdf. Accessed 28 Nov 2017

Polycarp IM, Odufote BO (2012) Enhancing Credit flow to the agricultural sector: the case of Central Bank of Nigeria's Commercial Agriculture Credit Scheme (CACS). The 8th AFMA Congress

Prowse M (2012) Contract farming in developing countries_a review. Agence Française de Développement (AFD). https:// repository.uantwerpen.be/docman/irua/04652f/1afof3f7.pdf. Accessed 15 Dec 2018

Ragaert P, Verbeke W, Devlieghere F, Debevere J (2004) Consumer perception and choice of minimally processed vegetables and packaged fruits. Food Quality Preference 15(3):259-270

Rajagopalan V (2000) Problems and prospects of agricultural development in Tamil Nado. In: Occasional Paper Nat. Bank for Agric. Rural Dev., Mumbai. 13, Vll: 160. http://krishikosh.egranth.ac.in/bitstream/1/413/1/R-13354.pdf. Accessed 11 Apr 2017

Razakaharivelo C (2013) Evaluation du produit crédit avec éducation. PAFIM, Madagascar https://info.undp.org/docs/pdc/ Documents/MDG/Madagascar_PAFIM_Evaluation_Impact_CAE\%202013.pdf. Accessed 12 Apr 2018

Shah MK, Khan H, Khan Z (2008) Impact of agricultural credit on farm productivity and income of farmers in mountainous agriculture in northern Pakistan: A case study of selected villages in District Chitral. Sarhad J Agric 24(4):713-718

Sheahan M, Barrett CB (2014) Understanding the agricultural input landscape in Sub-Saharan Africa: Recent plot, household, and community-level evidence. The World Bank Group, Washington

Sossou CH (2015) Le financement de l'agriculture au Bénin: stratégies de gestion et d'adaptation des exploitations agricoles. Doctoral dissertation, University of Liege-Gembloux Agro-Bio Tech, Belgium

Stiglitz J, Weiss A (1981) Credit rationing in markets with imperfect information. Am Econ Rev 71:393-410

Sulemana A, Dinye RD (2016) Microloans and agricultural sector incomes in developing countries: An empirical study of the Pru district in Ghana. Asian Econ Financial Rev 6(1):43-53

Tarchiani V, Rossi F, Camacho J, Stefanski R, Mian KA, Pokperlaar DS, Coulibaly H, Adamou AS (2017) Smalholder farmers facing climate change in West Africa: decision-making between innovation and tradition. J Innovation Econ Management 0:1-24

Taylor KA (1997) A regret theory approach to assessing consumer satisfaction. Marketing Letters 8(2):229-238

Thiessen C (2016) Equal harvests: How investing in agricultural development can empower women. Canadian Foodgrains Bank. https://www.foodgrainsbank.ca/wp-content/uploads/2015/01/Womens-paper-April-2016.pdf. Accessed 11 Apr 2017

Wampfler B, Lapenu C (2002) La microfinance au service de l'agriculture familiale: séminaire international 21-24 janvier 2002, Dakar, Sénégal. Résumé exécutif. http://hubrural.org//MG/pdf/cerise_microfinance_gricfamiliale_vf.pdf. Accessed 15 Dec 2018

World Bank (2011) World Development Report 2012: Gender equality and development. World Bank, Washington

Yabi RY (2013) Techniques de production du riz IR 841 dans les bas-fonds de la Commune de Glazoué - Département des Collines (Centre Bénin). Rapport final de protocole. http://www.ricehub.org/images/benin/scda-glazoue/productionrizicole-/files/Rap_FoReVA_riz_janvier_2013.pdf. Accessed 18 Dec 2018

\section{Publisher's Note}

Springer Nature remains neutral with regard to jurisdictional claims in published maps and institutional affiliations. 